\title{
Implementasi Kurikulum Muatan Lokal Berbasis Akhlak di Kabupaten Bangka Tengah
}

\author{
Suparta \\ Pascasarjana \\ IAIN Syaikh Abdurrahman Siddik Bangka Belitung, Indonesia \\ partasuparta23@yahoo.co.id
}

\begin{abstract}
Moral Education is the key to the success of education as a whole, both in the household, school, and community. During this time, a child is often only equipped with religious knowledge in the form of cognitive, while the inculcation of the foundations of faith is merely a slogan, an expression without reality. As a result, children have a lot of knowledge and intelligent brains, but have behaviors that are not in accordance with their knowledge. For this reason, the teachings of Islam should not be used as objects that are only studied and understood and memorized. However, the teachings of Islam must be subject to be understood, memorized and practiced. In fact, the tendency of teenagers today is to prioritize materialist and hedonic orientations, so that they are morally and spiritually poor. Thus the morality possessed is not an Islamic personality but an instant personality that he gets from the guidance of a misleading spectacle. To realize this expectation, there must be a local curriculum based on Akhak.
\end{abstract}

Keywords: Curriculum, Local Content, Moral Education

\begin{abstract}
Abstrak
Pendidikan Akhlak adalah kunci keberhasilan pendidikan secara keseluruhan, baik dalam rumah tangga, sekolah, maupun masyarakat. Selama ini, seorang anak sering hanya dibekali pengetahuan agama berupa kognitif saja, sedangkan penanaman dasar-dasar keimanan hanyalah slogan semata, ungkapan tanpa realitas. Akibatnya, anak mempunyai pengetahuan banyak dan berotak cerdas, namun mempunyai prilaku yang tak sesuai dengan ilmu yang dimiliki. Untuk itu, ajaran agama Islam jangan dijadikan obyek yang hanya dipelajari dan dipahami serta dihafalkan. Akan tetapi, ajaran agama Islam harus dijadikan subyek yang harus dipahami, dihafalkan dan diamalkan. Bahkan kecenderungan anak-anak remaja saat ini lebih mengedepankan orientasi materialis dan hedonis, sehingga miskin moral dan spiritual. Dengan demikian akhlak yang dimiliki bukanlah kepribadian Islami akan tetapi kepribadian instan yang didapatkannya dari tuntunan tontonan yang
\end{abstract}


menyesatkan. Untuk merealisasikan harapan tersebut maka harus ada kuriukulum muatan lokal yang berbasis Akhak.

Kata kunci: Kurikulum, Muatan Lokal, Pendidikan Akhlak

\section{A. Pendahuluan}

Di Bangka Tengah, Khususnya di daerah Koba dan Namang, ada peristiwa yang membuat Bupati Bangka Tengah malu. Karena adanya degradasi moral yang sedang mengancam para pelajar di Bangka Tengah. Adapun peristiwa tersebut berupa pergaulan bebas yang sangat memperihatinkan. Pergaulan bebas tersebut diabadikan lewat video porno yang disebarluaskan lewat media elektronik baik via handphone maupun via internet. ${ }^{1}$

Selain masalah dekradasi moral remaja berupa pergaulan bebas, ada juga ancaman berupa peredaran Narkoba. Hal ini terbukti dari data BNN 2010 ada sebanyak 3,6 juta anak pengguna narkoba. Dari 3,6 juta tersebut yang paling mencengangkan $63 \%$ nya masih usia remaja yaitu usia $13-18$ tahun $^{2}$. Bahkan data pada tahun 2013 ini lebih peredaran narkoba di Bangka Belitung mendapat peringkat ke enam nasional, nominal dalam bentuk uang peredarannya bisa mencapai $30-40 \mathrm{M}$ dalam sebulan ${ }^{3}$. Dari data tersebut dapat dikorelasikan bahwa tantangan pembinaan akhlak bagi remaja saat ini sangatlah berat. Untuk itu, diperlukan cara, strategi atau pun metode yang baik untuk mengantisipasinya.

Atas dasar peristiwa itulah akhirnya Bupati Bangka Tengah membuat kebijakan untuk sekolah tingkat SMP dan SMA se-Bangka Tengah masuk selama lima hari, mulai masuk jam 7.30-16.00 WIB. Pertimbangan utama beliau mengadakan kebijakan tersebut untuk meminimalisir kebebasan pergaulan para pelajar di luar sekolah. Diharapkan dengan kebijakan ini disetiap sekolah diadakan pembinaan moral tambahan yang dimasukkan dalam kurikulum muatan lokal. Tentunya pihak sekolah sifatnya membantu meminimalisir pergaulan bebas siswa, selebihnya harus ada juga pengawasan yang ketat dari masingmasing orang tua ${ }^{4}$.

\footnotetext{
${ }^{1}$ Wawancara dengan Kepala Sekolah SMP 2 Koba, Kabupaten Bangka Tengah, tanggal 13 Februari 2013 jam 14.30.

${ }^{2}$ Irkham, MSI, 'Refleksi hari anak nasional meretas masa depan anak, Bangka Pos, 23 Juli 2011.

${ }^{3}$ Lihat dalam Bangka Pos, Hari Sabtu, 23 Maret 2013.

${ }^{4}$ Drs. Herwan, Sekeretaris Kemendiknas Kabupaten Bangka Tengah, wawancara pada tanggal 14 Februari 2013, jam 9.30.
} 
Bahayanya jika ada beberapa orang tua yang berpendapat bahwa urusan mendidik anak adalah urusan sekolah. Sehingga baik atau buruknya moral anak adalah urusan sekolah. Persepsi ini tentunya sangatlah keliru, karena yang paling bertanggung jawab untuk mendidik anak-anak adalah orang tuanya ${ }^{5}$. Sebab, anak adalah amanah dari Allah swt yang harus dipertanggungjawabkan orang tua nanti di akherat.

Diadakannya jam tambahan untuk pembinaan moral yang diprakarsai oleh Bupati tentunya untuk menjawab alokasi pembelajaran PAI yang hanya dua jam dalam seminggu. Sebab, jika ditinjau dari alokasi waktu tersebut maka orientasi PAI untuk membentuk kepribadian siswa akan sulit mencapai target. Dengan adanya intruksi dan inovasi mata pelajaran PAI di luar jam Mata Pelajaran khusus pembinaan moral atau pembentukan kepribadian siswa oleh Bupati Bangka Tengah diharapkan pembentukkan moral dapat dijalankan dengan baik. Tentunya Intruksi dan inovasi ini harus dirancang dengan baik, Agar orientasi pembentukkan kepribadian atau membentuk pribadi yang berakhlakul karimah dapat berjalan dengan baik.

Selama ini di Bangka Bangka Tengah setiap SMP dan SMA sudah dilaksanakan kurikulum muatan lokal. Namun demikian, mayoritas kurikulum muatan lokal yang disampaikan belum ada materi yang berorientasi pada pembentukkan akhlakul karimah atau menurut istilah peneliti yaitu kurikulum muatan lokal yang berbasis akhlak. Muatan lokal yang dilaksanakan masih berupa keterampilan membaca Al-Qur'an (dengan metode Iqra') dan keterampilan berbahasa (bahasa arab atau inggris) juga berbentuk keterampilan kelautan. Padahal, menurut hemat peneliti yang paling penting bagi siswa SMP dan SMA pada saat ini adalah pembentukan kepribadian agar menjadi pribadi yang bukan hanya unggul intelektual akan tetapi juga unggul moral.

Pendidikan kepribadian inilah yang menjadi kunci keberhasilan pendidikan secara keseluruhan, baik dalam rumah tangga, sekolah, maupun masyarakat. Selama ini, seorang anak sering hanya dibekali pengetahuan agama berupa kognitif saja, sedangkan penanaman dasar-dasar keimanan hanyalah slogan semata, ungkapan tanpa realitas ${ }^{6}$. Akibatnya, anak

${ }^{5}$ Lihat dalam QS.At-Tahrim:6

${ }^{6} \mathrm{Hal}$ ini sebenarnya sejalan dengan yang diharapkan dalam Undang-Undang RI Nomor 2 Tahun 1989 yang kemudian dirubah menjadi Undang-undang RI Nomor 20 Tahun 2003 tentang Sistem Pendidikan Nasional masalah pendidikan Agama, moral dan etika mendapat perhatian besar. dalam bab I ayat I dan 2 dinyatakan bahwa (1). Pendidikan adalah usaha sadar dan terencana untuk mewujudkan suasana belajar dan proses pembelajaran agar peserta didik secara aktif mengembangkan 
mempunyai pengetahuan banyak dan berotak cerdas, namun mempunyai tingkah laku yang tak sesuai dengan ilmu yang dimiliki. Untuk itu, ajaran agama Islam jangan dijadikan obyek yang hanya dipelajari dan dipahami serta dihafalkan. Akan tetapi, ajaran agamaIslam harus dijadikan subyek yang harus dipahami, dihafalkan dan diamalkan.

Bahkan kecenderungan anak-anak remaja saat ini lebih mengedepankan orientasi materialis dan hedonis, sehingga miskin moral dan spiritual. Dengan demikian kepribadian yang dimiliki bukanlah kepribadian Islami akan tetapi kepribadian instan yang didapatkannya dari tuntunan tontonan yang menyesatkan. Atas dasar inilah peneliti menyatakan pentingnya diadakan konsep kurikulum muatan lokal PAI berbasis Akhlak di Bangka Tengah Kepulauan Bangka Belitung. Sehingga kurikulum yang ditawarkan lebih mengedepankan aspek pengamalan daripada hapalan, lebih mengedepankan kontekstualitas daripada tekstualitas.

\section{B. Dasar Pemikiran Kebijakan Pelaksanaan Kurikulum Muatan Lokal Berbasis Akhlak di Bangka Tengah}

Berdasarkan hasil wawancara dengan Bupati Bangka Tengah, Erzaldi Rosman Johan, SE.MM, dapat disimpulkan bahwa yang menjadi dasar pemikiran atas dilaksanakannya Muatan Lokal Berbasis Karakter ini terdiri dari empat dasar ${ }^{7}$. Adapun keempat dasar tersebut yaitu:

potensi dirinya untuk memiliki kekuatan spiritual keagamaan, pengendalian diri, kepribadian, kecerdasan, akhlak mulia, serta keterampilan yang diperlukan dirinya, masyarakat, bangsa dan negara. (2). Pendidikan Nasional adalah pendidikan yang berdasarkan pancasila dan UUD 1945 yang berakar pada nilai-nilai agama, kebudayaan nasional Indonesia, dan tanggap terhadap tuntutan dan perubahan zaman. Selanjutnya dalam I tentang Dasar, Fungsi dan Tujuan, pasal 3 dinyatakan, bahwa pendidikan nasional berfungsi mengembangkan kemampuan dan membentuk watak serta peradaban bangsa yang bermartabat dalam rangka mencerdaskan kehidupan bangsa, bertujuan mengembangkan peserta didik agar menjadi manusia yang beriman dan b ertaqwa kepda Tuhan Yang Maha Esa, berakhlak mulia, sehat, berilmu, cakap, kreatif, mandiri dan menjadi warga negara yang demokratis serta bertanggung jawab. (lihat di UU RI, Nomor 2 Tahun 2003 tentang SISDIKNAS, Jakarta, CV Ek Jaya, 2003.hlm.4, 5 dan 7 (dalam Abudin Nata, Pendidikan Islam di Era Global, Pendidikan Multikultural, Pendidikan Multin Iman, Pendidikan Agama, Moral dan Etika, Jakarta, UIN Jakarta Pers, 2005, hlm.418-419).

${ }^{7}$ Wawancara dengan Bupati Bangka Tengah, Bapak H. Erzaldi Rosman Johan, SE,MM pada tanggal 27 Maret 2013, Jam 9.00 - 10.30. Di Hotel Sabrina, Pangkal Pinang Bangka Belitung. 


\section{Dasar Yuridis}

Secara yuridis pelakasanaan pendidikan karakter ini merupakan program nasional yang didasarkan pada program Kemendiknas yang tertuang dalam surat edaran Menteri Pendidikan Nasional Nomor: 384/MPN/LL/2011 Tanggal 18 Juli 2011, hal pelaksanaan Pendidikan Karakter di seluruh Satuan Pendidikan. Tentunya hal ini sejalan dengan Undangundang Nomor 20 Tahun 2003 tentang Sistem Pendidikan Nasional (SISDIKNAS). Dalam Undang-undang tersebut menegaskan bahwa Pendidikan Nasional berfungsi mengembangkan kemampuan dan membentuk watak serta peradaban bangsa yang bermartabat dalam rangka mencerdaskan kehidupan bangsa. Sisdiknas bertujuan untuk mengembangkan potensi peserta didik agar menjadi manusia yang beriman dan bertaqwa kepada Tuhan Yang Maha Esa, Berakhlak Mulia, Sehat, berilmu, cakap, kreatif, mandiri dan mejadi warga negara yang demokratis serta bertanggung jawab.

Oleh sebab itu, realisasi dari pelaksanaan pendidikan karakter tersebut diwujudkan dengan cara membuat Peraturan Bupati Bangka Tengah, Nomor 79 Tahun 2011 tentang Pelaksanaan Pendidikan Karakter pada Satuan Pendidikan di Kabupaten Bangka Tengah. Adapun dasar dari Perbub ini adalah berdasarkan pancasila, Undang-undang Dasar 1945, dan Undang-undang Nomor 20 Tahun 2003 tentang Sistem Pendidikan Nasional ${ }^{8}$.

Dalam Perbup tersebut menyatakan bahwa pendidikan karakter berfungsi mengembangkan kemampuan dan membentuk watak serta peradaban bangsa yang bermartabat dalam rangka mencerdaskan kehidupan bangsa, bertujuan untuk berkembangnya potensi peserta didik agar menjadi manusia yang beriman dan bertaqwa kepada tuhan Yang Maha Esa, berakhlak mulia, sehat, berilmu, cakap, kreatif, mandiri dan menjadi warga negara yang demokratis serta bertanggung jawab. Selain itu, pendidikan karakter juga bertujuan mengembangkan nilai-nilai yang berkarakter bangsa yaitu pancasila yang meliputi ; 1). Mengembangkan potensi peserta didik agar menjadi manusia berhati baik, berpikiran baik dan berprilaku baik. 2). Membangun bangsa yang berkarakter pancasila. 3). Mengembangkan potensi warganegara agar memiliki sikap percaya diri, bangga pada bangsa dan negaranya serta mencintai umat manusia.

${ }^{8}$ Lebih lengkapnya dapat dilihat pada lampiran tentang peraturan Bupati Bangka Tengah Nomor 79 tahun 2011 tentang pelaksnaan pendidikan karakter pada satuan pendidikan di Bangka Tengah. 
Berdasarkan undang-undang dan Perbup tersebut jelaslah bahwa penekanan utama dari pendidikan nasional adalah mengembangkan potensi anak agar memiliki kepribadian yang baik atau memiliki karakter yang baik. Karakter tersebut diharapkan bermanfaat bukan hanya untuk dirinya saja akan tetapi bermanfaat pula bagi orang lain. Sebab, menurut beliau (Bupati) karakter anak remaja pada saat ini memang sangat buruk khususnya berkenaan dengan masalah pergaulan anak, ketaatan beribadah serta rentan terhadap penyalahgunaan obat-obatan terlarang yakni Narkoba. Dengan adanya program pemerintah tentang pendidikan karakter tersebut saya (Bupati) sangat setuju.

Atas dasar itulah maka Bupati Bangka Tengah dengan berani menginstruksikan kepada Kepala Dinas Pendidikan Nasional Bangka Tengah Drs.Sugianto untuk melaksanakan program tambahan jam pelajaran yang dikhususkan untuk pembinaan karakter. Sehingga waktu sekolah siswa SMP dan SMA se-Bangka Tengah menjadi lima hari dari senin-jum'at, masuk jam 7.00 dan pulang jam $16.00^{9}$.

Intruksi dari Bupati tersebut oleh Kepala Dinas Pendidikan Bangka Tengah dituangkan dalam Intruksi Dinas Pendidikan Nomor 400/341/DINDIK/2013 tentang Pelaksanaan Kegiatan Pembelajaran Pengembangan Peserta Didik Jenjang SMP/MTs dan SMA/SMK/MA di Kabupaten Bangka Tengah. Dalam intruksi tersebut dijelaskan bahwa alokasi waktu belajar hari senin sampai kamis masuk jam 7.00 pulang jam 16.00. hari jum'at masuk 7.00 pulang jam 15.00 .

Hal ini dibenarkan oleh Drs.Herwan selaku Sekretaris Kemendiknas Bangka Tengah. Beliau mengatakan bahwa saat ini Kemendikanas Bangka Tengah sedang merancang, menyususn program untuk pembinaan karakter khususnya di tingkat SMP dan SMA se- Bangka Tengah. Secara jujur beliau mengatakan bahwa pelaksanaannya saat ini masih diserahkan kepada sekolah masing-masing, jadi belum ada format atau kurikulumnya. Makanya saat ini sedang menjadi pembahasan serius agar ada format atau kurikulum muatan lokal berbasis karakter atau akhlak ${ }^{10}$.

${ }^{9}$ Hal ini sudah diketahui juga oleh Drs.Faizal, M.Pd, selaku Kepala Bidang Pendidikan Menengah (yakni khusus untuk tingkat SMP dan SMA/SMK) se Bangka-Tengah, beliau mengatakan bahwa memang benar bapak Bupati sudah menginstruksikan kepada kita agar seluruh sekolah tingkat SMP-SMA/SMK agar masuk lima hari mulai masuk jam 7.30 dan pulannya jam 16.00. bahkan sudah hampir dua bulan ini sudah berjalan. (wawancara pada tanggal 27 Maret 2013 jam 8.00 di Kantor Bupati Bangka Tengah.

${ }^{10}$ Hasil wawancara dengan Drs.Herwan, Sekretaris Kemendiknas Bateng pada tanggal 18 Februari 2013 jam 10.00 di Ruang Kerjanya di Kemendiknas Bateng. 
Begitu juga halnya dengan yang diungkapkan oleh Bupati Bangka Tengah, H.Erzaldi, SE,MM beliau mengatakan bahwa sampai saat ini belum ada format atau program yang sistematis untuk mengisi program pelaksanaan pembinaan moral ini. Untuk itu, beliau mengharapkan kepada Dinas Pendidikan Bangka Tengah agar segera menyusun format atau kurikulum yang berbasis karakter atau akhlak ${ }^{11}$.

Bahkan agar payung hukumnya makin kuat saat ini Pemda Bateng sedang menyusun perda tentang Pengelolaan dan Penyelenggaraan Pendidikan. Sehingga harapan yang dicitacitakan oleh Pemda Bangka Tengah tentang pembentukkan kepribadian yang berkarakter akan bisa terwujud. Tentunya program atau pedoman kurikulum yang dijalankan adalah sebuah panduan yang memiliki materi yang kontekstual juga mengedepankan model pembelajaran yang menyenangkan. Sebab, pembelajaran ini dilaksanakan diluar jam pelajaran atau berupa jam tambahan.

\section{Dasar Birokratis}

Sebagai Bupati paling tidak memiliki jabatan ganda, selain jabatan politis juga jabatan birokratis. Untuk itu, sebagai birokrat tentunya kebijakan ini harus melibatkan semua jajaran yang terkait dengan permasalahan karakter ini. Maka dari itu, dalam pelaksanaannya tidak mungkin bupati akan melaksanakannya sendirian, akan tetapi harus ada dukungan dari berbagai pihak terutama pihak-pihak yang berkorelasi langsung dengan masalah pembinaan karakter anak.

Adapun pihak-pihak yang terkait ini diantaranya adalah DPRD, Wakil Bupati, Sekda, Dinas Pendidikan, Kemenag, Semua Sekolah tingkat SMP dan SMA/SMK, BNK Bangka Tengah, Majlis Ulama Indonesia Bateng, BKPRMI Bateng, NU dan Muhammadiyah. Semua pihak tersebut diharapkan dapat bekerja sama untuk menyukseskan program ini, tentunya yang tidak kalah pentingnya adalah para orang tua siswa.

Agar pelaksanaan ini dapat terlaksana dengan baik, menurut Bupati harus ditanamkan sifat keihklasan pada semua pihak. Sebab, bila ikhlash Insya Allah semua pihak akan dengan senang hati dan bersama-sama menjalankan program ini. Tugas ini adalah tugas

${ }^{11}$ Bahkan saat wawancara dengan beliau, berharap ada tim ahli atau pakar pendidikan yang dapat mendesaign kurikulum muatan lokal berbasis akhlak ini. Untuk itu, beliau sangat apresiatif sekali jika disertasi ini nantinya bisa menjadi bahan acuan atau buku panduan praktis untuk melaksanakan program muatan lokal berbais akhlak di Bangka Tengah. (wawancara tanggal 27 Maret 2013 jam 9.00) 
mulia, dikatakan mulia karena menyangkut nasib atau masa depan anak-anak kita. Bila bukan kita yang memulainya siapa lagi? Bila bukan sekarang juga dimulainya, mau kapan lagi? Maka jelaslah tidak ada kata tidak untuk membenahi moralitas remaja ini. ${ }^{12}$

Untuk itu, beliau akan berusaha mengajak pihak-pihak yang berkepentingan dengan masalah moral ini. Kehusunya dengan Kemendiknas dan Kemenag yang menaungi tingkat satuan pendidikan mulai dari SMP sampai SMA. Untuk para orang tuanya sesekali Bupati menyarankan kepada MUI untuk mengirimkan para Da'inya agar memberikan pencerahan atau siraman rohani kepada para orang tua murid tentang pentingnya pendidikan anak terutama pendidikan agama dan moralnya. Dengan demikian diharapkan para orang tua pun akan menyadari betapa pentingnya pendidikan moral bagi anak-anaknya.

\section{Dasar Politis}

Jabatan Bupati tentunya termasuk dalam kategori jabatan politis. Namun demikian beliau tidak ada niat bahwa program ini adalah untuk menjadikan dirinya bisa lebih hebat dari para bupati lainnya yang ada di Babel atau di Indonesia. Bagi beliau, pembinaan moral yang akan dilaksanakan di Bangka Tengah ini lebih dari kewajiban dirinya sebagai pimpinan yang nantinya akan dimintai pertanggungjawabannya di akherat kelak. Sebab, beliau berasumsi bahwa degradasi moral yang terjadi dikalangan remaja saat ini bila diumpakan virus sudah sangat membahayakan, lebih bahaya dari virus HIV. Bahkan bila dianggap musibah sudah melebihi dari musisbah tsunami ${ }^{13}$. Dengan demikian, degradasi moral yang ada di Bangka Tengah ini sudah sangat mempprihatinkan.

Makanya ungkap beliau, selagi masih bisa berbuat sesuatu karena masih diberikan kepercayaan atau amanah dari rakyat sebagai pimpinan di Bangka Tengah ini maka saya (bupati) akan memberanikan diri menetapkan atau menjalankan program pembinaan moral ini walaupun mungkin banyak menghadapi tantangan dan hambatan. Ketika ditanyakan apakah ada tantangan dan hambatan dalam melaksanakan program ini? Beliau pun secara tegas mengatakan "oh..jelas ada!!". Apa tantangan atau hambatannya pak? Beliau

${ }^{12}$ Dengan penuh harap dan motivasi yang luar biasa saat wawancara beliau mengatakan demikian, ini salah satu kewajiban yang harus dilaksanakan oleh seorang pimpinan kata beliau, untuk itu, selagi saya menjadi pimpinan di bangka tengah maka saya akan dengan sekuat tenaga dan semaksimal mungkin memperjuangkan pembinaan moral ini. (wawancara pada tanggal 27 Maret 2013 jam 10.00) jam 9.25

${ }^{13}$ Ungkapan ini diucapkan Bapak Bupati ketika diwawancara pada tanggal 27 maret 2013 
mengatakan tantangan tersebut tentunnya datang dari internal ataupun eksternal. Secara internal (maksudnya dalam wilayah birokrasi) tentunya tidak semua pihak menyambut baik program ini. Secara eksternal bisa saja di kalangan sekolah atau masyarakat khususnya orang tua tidak semuanya setuju. Hanya saja sampai saat ini belum ada penelitian khusus tentang masalah hambatan dan tantangan tersebut. Tapi saya yakin setiap kebaikan pasti ada yang tidak menyukainya, karena antara kebenaran dan kebathilan akan selalu bertentangan dari dulu sampai akhir zaman ${ }^{14}$.

\section{Dasar Religi}

Selain ketiga dasar di atas, tentunya yang tidak bisa ditinggalkan dan tidak kalah pentingnya untuk menjadi dasar pemikiran dilaksnakannya program muatan lokal berbasis karakter ini adalah dasar religi. Bila bagi umat Islam maka yang menjadi patokan utama dalam mengajarkan atau membuat panduan muatan lokal berbasis karekter ini adalah AlQur'an dan Al-Hadits ${ }^{15}$. Sebab, pada dua sumber inilah sebenarnya model ataupun konsep karakter sangat jelas konsepnya. Didalamnya penuh dengan uraian atau ajakan bagaimana caranya menjadi manusia yang memiliki karakter yang baik.

Untuk itu, diharapkan dalam panduannya atau kurikulmnya akan tertuang tentang kepribadian Rasulullah SAW, para sahabat nabi dan para ulama-ulama lain yang memiliki kepribadian atau karakter yang baik. Bisa saja dalam setiap materi akan diberikan contoh atau teladan langsung yang diambil dari kisahnya nabi Muhammad SAW atau para sahabat dan ulama yang lainnya. Selain itu, setiap materi disertai dengan beberapa dalil Al-Qur'an dan haditsnya. Dengan demikian para peserta didik atau siswa mejadi tidak bosan dalam mengikuti pemebelajarannya. Begitu juga dengan non muslim mereka akan dibimbing oleh

${ }^{14}$ Bahkan istilah beliau, jangan kita manusia biasa yang banyak salah dan dosanya, sedangkan rasulullah saw saja pada saat melaksanakan dakwahnya banyak sekali tantangan dan hambatannya. Bukan hanya tenaga, harta dan jabatannya yang dipertaruhkannya akan tetapi jiwanya pun dipertaruhkannya demi tegaknya kebenaran islam. Adapun tantangan itu datangnya seperti dari orang-orang kafir Quraisy yakni Abu Jahal dan Abu Lahab serta yang lainnya. (wawancara tanggal 27 Maret 2013 jam 9.45)

${ }^{15} \mathrm{Hal}$ ini diungkapkan oleh Bupati Bangka Tengah secara tersirat, beliau mengatakan bahwa pembinaan moral yang baik adalah dengan cara pembiasaan, karena pendidikan moral atau karakter akan bisa diwujudkan dengan cara dibiasakan. Pembiasaan ini diantara dengan cara atau strategi agar anak mencintai kitab sucinya masing-masing, selain itu harus ada keteladanan dengan cara mengisahkan keteladanan rasulullah juga para sahabat-sahbat yang lainnya khususnya tentang kemuliaan akhlak mereka. Dengan demikian para siswa akan senang dan tergerak untuk mencintai kitab sucinya dan mengikuti jejak para Nabi dan pra sahabat-sahabatnya. (wawancara, tanggal 26 Maret 2013 jam 9.30). 
para pembina mereka yang juga bersumber dari kitab sucinya masing-masing. Sebab, di SMP, SMA atau pun SMK tidak sedikit juga yang beragama non muslim.

\section{Faktor-faktor yang Melatarbelakangi Kebijakan Muatan Lokal Berbasis Akhlak di Bangka Tengah}

Ketika Bupati Bangka Tengah, H.Erzaldi, SE,MM diwawancarai masalah faktorfaktor apakah yang melatarbelakangi beliau membuat kebijakan tentang muatan lokal berbasis karakter. Beliau mengawalinya dengan istilah "tiada asap jika tiada apinya, tiada akibat jika tidak ada sebabnya"16. Untuk itu, dibuatnya kebijakan tersebut dikarenakan beberapa faktor yaitu:

\section{Faktor Degradasi Moral Siswa}

Beberapa kali beliau mengatakan bahwa perjuangan yang paling berat yang sangat mendesak dan harus segera dilaksanakan adalah pembinaan moral terhadap siswa. Bahkan menurut beliau, masalah moralitas siswa ini bagaikan wabah virus yang sangat membahayakan. Bila tidak segera dibenahi atau diobati maka penularannya tidak akan bisa dibendung lagi. Degradasi moral yang paling berbahaya bagi para remaja saat ini adalah pergaulan bebas ${ }^{17}$. Tentunya pergaulan bebas yang dialami oleh para remaja ini adalah akibat pengaruh negatif dari pesatnya sains dan tehnologi. Hanya dalam hitungan detik para siswa ini bisa mendapatkan informasi, data, gambar atau film yang berbau pornografi dari sesama kawannya. Tentunya semua itu bisa meraka dapatkan dari internet. Melalui media tersebut mereka bergaul, belajar dan saling memberikan aura negatif antara mereka bahkan dengan orang lain.

Adapun yang paling menghebohkan adalah beredarnya Video Porno yang dilakukan oleh seorang anak kelas 2 SMP dengan seorang duda umur 20 tahun beranak satu di daerah Koba Bangka Tengah ${ }^{18}$. Tidak berapa lama kemudian adalagi perbuatan mesum yang

${ }^{16}$ Wawancara dengan Bupati Bangka Tengah, H.Erzaldi Rosman Johan, SE, MM, pada tanggal 26 Maret 2013, jam 9.00.

${ }^{17}$ Pendapat Bupati tersebut, senada dengan yang diungkkapkan oleh Kepala Dinas Pendidikan Nasional, Bangka Tengah, Drs.Sugiyanto, faktor yang melatarbelakangi mengapa harus diadakan tambahan jam untuk pembinaan moral di Bangka Tengah ini karena pergaulan bebas sudah mulai menjadi virus yang sangat membahayakan bagi anak-anak remaja. Selain itu, fungsi kontrol sosial sudah mulai berkurang. Maka jika tidak digalakkan program pembinaan moral ini, generasi muda mendatang akan berada pada posisi yang memprihatinkan. (wawancara dengan Drs.Sugiyanto, Kepala Kemendiknas, Bangka Tengah, tanggal 1 April 2013, jam 18.30).

${ }^{18}$ Lihat Bangka Pos, Sikap Kami, Video Porno Mengguncangkan Koba, 7 Januari 2013. 
dilakukan dikontrakan tepatnya di Daerah Namang yang dilakukan oleh Anak-anak seusia SD dan SMP.

Tentunya kasus Video Porno dan Tindakan Mesum yang dilakukan oleh anak-anak yang masih dalam kategori SMP ini menunjukkan kepada masayarakat Babel bahwa saat ini pergaulan bebas, seks bebas dikalangan remaja sudah sangat memprihatinkan. Perkara seks yang semestinya baru mereka dapatkan secara teori melalui pelajaran Biologi disekolah, kini justru mulai banyak dipraktekkan langsung oleh oknum pelajar baik dipinggiran kolong (kolong adalah bentuk danau yang terbuat dari akibat bekas-bekas penambangan di daerah area pertambangan timah), dikamar kost, di hutan-hutan bahkan di pinggiran pantai.

Atas dasar beberapa kejadian amoral di atas, menjadi bukti empiris bahwa akhlak siswa di Babel saat ini pada posisi yang harus dan wajib diperhatikan. Atas dasar ini pula akhirnya Bupati Bangka Tengah pun, setelah adanya kejadian tersebut seolah menyadari betul bahwa saat ini di daerahnya sedang dilanda degradasi moral. Untuk itu, beliau (Bupati Bangka Tengah, Erzaldi Rosman Johan) menginstruksikan Dinas Pendidikan Bangka Tengah, mewajibkan jam tambahan belajar khusus untuk anak-anak SMP dan SMA di Bangka Tengah. Kata beliau " kalau melihat dua kasus amoral ini (video porno dan perbuatan mesum di kontrakan namang) ternyata moral anak bangsa sedang menurun, padahal di Kabupaten Bangka Tengah sudah dilakukan pendidikan karakter dan ngaji untuk meminimalisir perbuatan amoral"19 Untuk itu, pendidikan karakter yang diadakan di sekolah harus dirancang dengan baik, serta harus ada kerjasama antara sekolah, orang tua dan masyarakat.

Permasalahan bangsa tersebut di atas semakin diperparah dengan tayangan telivisi yang sangat vulgar, life, tidak mengenal waktu tayang, dan diulang-ulang oleh hampir semua stasiun TV dan juga surat kabar. Peristiwa pembunuhan, pemerkosaan, perkelaian, perampokan, pembakaran, demo yang anarkis, tidakan aparat yang represif, perceraian, terorisme dan berbagai bentuk tindakan kejahatan justru menjadi menu utama dan disiarkan dalam berbagai bentuk tayangan (berita, peristiwa, sinetron, dialog dan lain-lain). Semboyan wartawan adalah "bad news is good news". Berita baik apabila ada unsur "blood" dan "crowd". Tindakan memperolok, memfitnah, menghina, mengadu domba, pembunuhan karakter justru difasilitasi oleh media.

\footnotetext{
${ }^{19}$ Bangka Pos, Siswa Bakal Pulang Sekolah pukul 16.30 WIB, 11 Januari 2013
} 
Fenomena di atas, apabila kita renungkan akan menimbulkan keprihatinan yang mendalam. Prihatin terhadap kualitas generasi muda di masa depan, prihatin terhadap citra dan daya saing bangsa kita yang semakin rendah dan direndahkan oleh bangsa-bangsa lain. Kita juga prihatin terhadap stigma terhadap sebagian umat Islam yang diidentikkan dengan teroris, anti intelektual dan anti peradaban.

Berbagai permasalahan tersebut diasumsikan bersumber dari krisis etika dan moral: bisa korupsi dianggap prestasi, penipuan dianggap lumrah asalkan tidak keterlaluan, hilangnya budaya malu (marwah), hilangnya keperawanan tidak lagi disesalkan, politik uang untuk membeli kekuasaan, berbudi bahasa yang santun dianggap suatu kelemahan, agama tidak lagi dipedomani sebagai akhlak melainkan sebagai alat kepentingan dan kekuasaan, dan bahasa kekerasan adalah bahasa kekuasaan dan ketertindasan ${ }^{20}$.

Kondisi tersebut tentu saja sangat memprihatinkan. Kondisi ini menuntut semua pihak untuk mengambil peran masing-masing guna menyelamatkan generasi muda dan bangsa. Kaum agamawan sebagai penjaga etika dan moral masyarakat termasuk di dalamnya guru agama harus diberdayakan agar dapat mengambil peran secara signifikan. Demikian juga pendidikan agama yang memiliki peran strategis harus semakin ditingkatkan mutu dan relevansinya bagi upaya pembangunan moral bangsa. Pendidikan agama di sekolah perlu direkonstruksi agar dapat memerankan tugas dan fungsinya secara efektif yaitu membangun akhlak (etika dan moral) generasi penerus bangsa. Rekonstruksi itu meliputi aspek filosofis, substantif dan metodologis ${ }^{21}$.

Eksistensi, kemuliaan dan kejayaan sebuah bangsa tergantung akhlaknya, demikian juga keterpurukan, kehinaan dan kehancurannya. Awal dan sumber segala kebaikan adalah akhlak, demikian juga segala keburukan bersumber dan bermuara kepada akhlak. Apabila

${ }^{20}$ Adanya krisis etika dan moral dalam kehidupan bermasyarakat, berbangsa dan bernegara, bahkan juga krisis etika dan moral dalam beragama lantas memunculkan pertanyaan tentang peranan dan sumbangan Pendidikan Agama Islam (PAI) dalam membentuk etika dan moral. Walaupun variabel perkembangan permasalahan tersebut sesungguhnya sangat kompleks, namun seringkali secara langsung maupun tidak langsung dihubungkan dengan permasalahan pendidikan agama di sekolah. Pertanyaan seperti ini dianggap sah-sah saja karena sumber dari berbagai permasalahan tersebut adalah akibat adanya krisis etika dan moral, sedangkan tugas pokok pendidikan agama adalah membentuk anak didik memiliki moralitas dan akhlak budi pekerti yang mulia.

${ }^{21}$ Lihat dalam Makalah Prof.Dr.Tobroni, Pendidikan Karakter dalam Perspektif islam, Pemakalah adalah guru besar Filsafat Pendidikan FAI/PPS UMM, Anggota Majlis Dikti PP Muhammadiyah, Anggota BAN PT Kemendiknas, Visiting Professor di University of Malaya Malaysia 2009-2010. 
sebuah bangsa mengalami krisis moral dan akhlak, maka bangsa tersebut akan berbuat dlalim, berbuat kerusakan terhadap alam maupun kedlaliman terhadap sesamanya. Dampak dari kedzaliman tersebut adalah timbulnya berbagai musibah, balak dan bencana, baik yang bersumber dari alam seperti maupun manusia.

Hal ini disebabkan, penegakkan moral atau akhlak mulia bangsa merupakan suatu keharusan mutlak. Karena aklak mulia akan menjadi pilar utama untuk tumbuh dan berkembangnya peradaban suatu bangsa. Kemampuan suatu daerah atau bangsa untuk bertahan hidup ditentukan oleh sejauh mana masyarakat dari daerah tersebut terutama pimpinannya menjunjung tinggi nilai-nilai akhlak atau moral. Semakin baik akhlak dan moral suatu daerah maka akan semakin baik pula daerah bersangkutan, tentunya demikian pula sebaliknya ${ }^{22}$.

Adapun Model atau Format pembelajaran atau pembinaan moral ini saat ini sedang dikonsep yang akan dituangkan dalam bentuk kurikulum yang berbasis moral atau akhlak. Untuk saat ini, tiap satuan sekolah baik tingkat SMP maupun SMA sudah mulai melakukan pembinaan moral siswa dengan cara membiasakan membaca Al-Qur'an, Shalat berjama'ah dan mendatangkan muballigh dari luar untuk membina rohani siswa.

\section{Faktor Ancaman Narkoba}

Sebelum menjabat sebagai Bupati, H.Erzaldi Rosman Johan,SE,MM juga pernah menjabat sebagai Wakil Bupati pada periode sebelumnya. Sebagai wakil bupati saat itu beliau juga diberikan amanah jabatan tambahan sebagai Ketua Badan Narkotika Kabupaten Tengah. Mulai saat itu, beliau pun sangat konsen untuk memberantas narkotika khususnya di wilayah Bangka Tengan. Bukti kesriusannya diantaranya diwujudkan dalam bentuk dibuatnya Modul sosialisai anti narkoba.

${ }^{22}$ Hal ini sesuai dengan yang diungkapkan oleh Prof.Dr.H.Said Agil Al Munawar, MA (lihat dalam bukunya “Aktualisasi Nilai-nilai Qur' ani dalam Sistem Pendidikan Islam, Ciputat, PT.Ciputat Press, 2005, hlm.25-26) memasuki era reformasi khusunya di Indonesia, pembinaan akhlak memiliki nilai yang sangat strategis dalam mewujudkan reformasi diberbagai beidang. Sebab, perubahan yang tidak dilandasi dengan akhlak yang mulia hanya akan menjadi slogan dan klise semata . Nilai-nilai aklak mulia sebagaimana diajarkan dalam agama Islam harus menjadi landasan utama dalam reformasi. Akhlak merupakan alat kontrol psikis dan sosial bagi individu dan masyarakat. Tanpa akhlak manusia akan sama dengan kumpulan binatang yang tidak memahami makna penting dari kehidupan. Bahkan faktor utama yang menyebabkan tumbuh suburnya praktek - praktek korupsi, kolusi dan nepotisme dan perkembangan kecenderungan manusia berbuat sadisme, kriminalitas dan porno aksi ataupun pornografi disebabkan rendahnya moral atau akhlak yang dimilikinya. 
Apalagi saat ini sudah menjadi Bupati, maka keseriusan untuk memberantas Narkoba ini makin ditingkatkan. Wujud dari keseriusannya untuk memberantas Narkoba khususnya dikalangan siswa Bupati Bangka Tengah sudah mengadakan MOU dengan pihak TNI dan POLRI Bangka Tengah. Realisasi program ini diantaranya dengan cara bekerjasama melatih karakter siswa serta mengadakan razia tiap sebulan atau dua minggu sekali ke sekolah-sekolah. Hal ini dimaksudkan agar para siswa menjadi siswa yang terbebas dari pengaruh atau pun target pengedar Narkoba.

Berdasarkan informasi dari Badan Narkotikan Nasional Propinsi Bangka Belitung, pengguna dan pengedar Narkoba di wilayah Kepulauan Bangka Belitung ini sangat mengkhawatirkan. Hal ini terbukti dari berita yang diungkap oleh harian Bangka Pos bahwa Babel menjadi pasar Narkoba. Belanja narkoba di Babel setiap bulannya mencapai Rp.40 Miliar bahkan jika dikalkulasikan dalam waktu setahun sampai pada angka 500 Miliar (setengah triliun). Hal ini dipertegas dengan hasil survei badan Narkotika Nasional Propinsi Bangka Belitung bekerja sama dengan Pusdiklat Universitas Indonesia pada tahun 2012, data transaksi sabu-sabu setiap bulannya bisa mencapai jumlah 10 sampai 15 kilogram. Nilai sabu-sabu ini 1 miliar sampai 2 miliar perkilogramnya ${ }^{23}$.

Adapun jenis narkoba lain, selain sabu-sabu yang sudah populer yang sudah beredar di Babel adalah ekstasi yang ditaksir memiliki pasaran 1.500 butir perbulan dengan harga Rp.200.000 perbutir. Selain ekstasi ganja juga beredar di daerah babel dalam sebulan transaksinya bisa mencapai antara 40-50 Kg perbulan dengan harga Rp. 4-5 juta perkilogramnya. Dari tiga jenis narkoba ini saja jika dikalkulasikan hasil dari transaksinya bisa mencapai 35 - 40 Miliar perbulan. Dengan kata lain uang yang didapat dari Narkoba selama tahun 2012 bisa mencapai 480 Miliar. Ini adalah jumlah angka yang sangat mengejutkan, berarti moral anak-anak remaja pada saat ini sedang dalam posisi diujung tanduk yang sangat membahayakan.

Oleh sebab itu, propinsi Babel yang hanya dihuni oleh penduduk 1,2 Juta orang ini memiliki peringkat 6 besar transaksi narkoba pada tingkat nasional. Peringkat ini adalah peringkat yang sangat buruk bagi keberlangsungan generasi muda kedepan. Sebab, para siswa akan selalu dihadapkan pada posisi pengaruh yang negatif baik dari lingkungannya,

${ }^{23}$ Lihat dalam Bangka Pos, Babel Jadi Pasar Narkoba:empat Polisi jadi Tersangka, Sabtu, 12 Januari 2013. 
maupun dari teman-teman sejawatnya. Sebab, berdasarkan data dari BNN Pemprop Babel, jumlah pengguna Narkoba saat ini sudah mencapai 12.000 orang. Adapun yang paling banyak penggunanya adalah pada usia produktif atau usia remaja yaitu usia 11-20 tahun 29 orang dan usia 21-30 tahun sebanyak 115 orang $^{24}$.

Berdasarkan beberapa data tersebut, memberikan data tersirat bahwa yang diketahui saja seperti itu banyaknya, bagaimana dengan yang belum diketahui. Sebab, setiap aspek kaejahatan dan keburukkan yang tersembunyi selalu bagaikan gunung es, yang kelihatan baru puncaknya saja sementara badannya belum nampak. Dengan demikian jelaslah bahwa moral siswa jika tidak segera diantisipasi maka ke depan generasi muda Babel bisa berbahaya.

\section{Faktor Minimnya Alokasi Waktu untuk Pendidikan Agama}

Harapan utama dari orang tua, guru maupun masyarakat terhadap generasi muda khususnya usia remaja menjadi sosok remaja yang anggun secara moral dan tangguh secara intelektual. Secara moral, akhlak para remaja dapat menyejukkan dan membanggakan kedua orang tuanya, dapat membanggakan para guru yang mendidiknya bahkan dapat menjadi kebanggaan bagi masyarakat sekitarnya. Demikian juga halnya dari segi intelektualnya, selalu menunjukkan prestasi-prestasi yang dapat membanggakan orang tua, mengagumkan para gurunya dan menjadi kebanggaan masyarakat.

Itulah sebabnya, pendidikan agama menjadi wajib dilaksanakan di setiap satuan pendidikan di Indonesia memiliki tujuan mulia yaitu membentuk manusia yang beriman dan bertaqwa serta berakhlak mulia (insan kamil). Sebab, kejayaan seseorang terletak pada akhlak yang baik, akhlak yang baik akan membuat seseorang menjadi aman dan tenang karena tiada perbuatan yang tercela. Bahkan cerminan dari orang yang berakhlak mulia ini akan menimbulkan energi positif terhadap dirinya, melaksanakan segala perintah Allah serta berbuat baik terhadap sesama manusia.

Ketika siswa tersebut berada didalam rumah, maka tiada ucapan, sikap dan prilaku yang ditampilkannya terhadap kedua orang tuanya kecuali ucapan yang santun, sikap yang sopan dan prilaku yang membanggakan. Bahkan ia senantiasa taat dan patuh terhadap orang tuanya serta selalu membantu orang tua dengan tanpa beban. Ketika di sekolah selalu taat dan patuh pata tata tertib sekolah, hormat dan taat pada gurunya, serta menjadi kebanggaan

\footnotetext{
${ }^{24}$ Ibid, hlm 7.
} 
bagi kawan-kawannya, para guru dan karyawan sekolah. Demikian juga jika berada di masyarakat, tatakramanya sopan santun, sikap dan prilakunya selalu menyenangkan semua orang, ketaatan dalam beragamanya dapat dijadikan teladan bagi anak-anak yang lainnya.

Jika semua siswa memiliki mentalitas yang baik maka secara universal Indonesia memiliki modal yang besar untuk kepemimpinan bangsa di masa yang kan datang. Akan tetapi modal yang besar itu seakan tidak banyak berarti apabila mentalitas bangsa ini belum terbangun atau belum berubah ke arah yang lebih baik. Selama mental sebuah bangsa tersebut tidak berubah, maka bangsa tersebut juga tidak akan mengalami perubahan dan akan tertinggal dengan bangsa-bangsa lain, meskipun bangsa tersebut sesungguhnya memiliki potensi dan modal yang besar. Allah dalam hal ini secara tegas mengatakan dalam QS. 13:11:

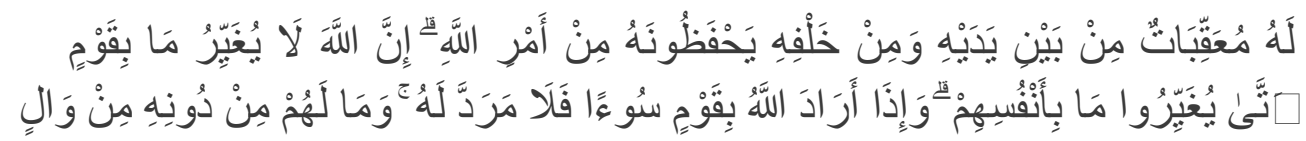

Bagi manusia ada malaikat-malaikat yang selalu mengikutinya bergiliran, di muka dan di belakangnya, mereka menjaganya atas perintah Allah. Sesungguhnya Allah tidak merobah Keadaan sesuatu kaum sehingga mereka merobah keadaan yang ada pada diri mereka sendiri. dan apabila Allah menghendaki keburukan terhadap sesuatu kaum, Maka tak ada yang dapat menolaknya; dan sekali-kali tak ada pelindung bagi mereka selain Dia.

Media yang paling ampuh untuk merubah mentalitas bangsa adalah lewat pendidikan dan keyakinan agama. Pendidikan yang mampu merubah mentalitas adalah pendidikan yang dilaksanakan dengan sungguh-sungguh dan sepenuh hati, bukan hanya sekedar formalitas atau kepura-puraan. Keyakinan agama juga besar pengaruhnya bagi mentalitas bangsa. Karena itu melalui pendidikan agama yang mampu menanamkan keimanan yang benar, ibadah yang benar dan akhlakul karimah, niscaya akan menjadikan anak didik sebagai manusia terbaik, yaitu yang bermanfaat bagi orang alain melalui amal shalehnya.

Dengan demikian, posisi pendidikan agama sangatlah penting untuk membentuk karakter atau kepribadian anak. Namun demikian, posisi Pendidikan Agama yang strategis ini tidak dibarengi dengan pelkasanaan yang strategis pula. Alokasi waktu mata pelajaran ini hanya dua jam dalam seminggu. Maka idealisme yang tinggi, idealisme yang diharapkan 
melalui pendidikan agama tersebut para siswa menjadi baik menjadi melangit, belum menyentuh bumi. Maka dari itu, salah satu solusi alternatif yang baik adalah dengan cara memberikan jam tambahan khusus pembinaan moral untuk menjawab kurangnya alokasi waktu PAI tersbut.

\section{Faktor Budaya Melayu yang Mulai Dikesampingkan}

Menurut Kepala Kementerian Pendidikan Nasional Bangka Tengah, Drs. Sugiyanto, saat ini anak-anak (para siswa) sudah malas mengikuti budaya-budaya melayu yang telah dicontohkan oleh para orang tua dulu. Istilahnya kata beliau adalah "local wisdom" yakni kebijakan lokal atau kebudayaan lokal yang telah dilaksnakan secara turun temurun dari masa dulu hingga sekarang. Padahal, menurut beliau, budaya ini sangat baik untuk memupuk jiwa sosial sekaligus moral bagi anak-anak ${ }^{25}$.

Adapun budaya yang mulai tinggalkan oleh para anak-anak saat ini diantaranya, budaya nganggung. Padahal dalam budaya ini penuh makna atau filosofi bagi kehidupan manusia. Nganggung adalah budaya membawa makanan ke mesjid pada acara-acara tasyakuran atau hari-hari besar islam lainnya. Adapun tempat untuk bawa makanannya menggunakan tempat khusus yang biasa disebut nampan dan tutupnya disebut tudung saji. Dalam acara ini semua masyarakat berkumpul di mesjid tanpa membedakan antara yang kaya dengan yang miskin, antara yang berpangkat dengan rakyat biasa, serta antara yang muda dan yang tua. Inilah ajang silaturrahim, tanpa dibatasi status sosial dan status intelektual. Semuanya dijalankan untuk memberikan makna bahwa kita hidup harus bersatu, bergotong royong serta saling tegur sapa antara yang satu dengan yang lainnya.

Filosofi persatuan dan kebersamaan inilah yang harus dibudayakan. Terlebih dalam budaya ini ada unsur kontrol sosialnya antara masyarakat. Yaitu dengan saling nasehat menasehati tentang kebenaran dan kesabaran. Pengaruh budaya ini tentunya berimplikasi kontrol sosial masayarakat yang tinggi antara sesama warganya. Terutama terhadap penyakit-penyakit sosial seperti, kenakalan remaja, pergaulan bebas serta penyakit sosial lainnya.

Namun demikian, menurut Drs. Sugiyanto, budaya ini makin lama makin memudar. Khususnya dikalangan anak-anak remaja. Mereka berasumsi bahwa budaya ini kuno, alias

${ }^{25}$ Wawancara dengan Kepala Kementerian Pendidikan Nasional Kabupaten Bangka Tengah, pada tanggal 1 April 2013, jam 18.30. 
ketinggalan zaman. Mereka lebih mengagumi budaya barat daripada budayanya sendiri yaitu budaya melayu. Dengan kata lain, daripada nongkrong di mesjid lebih baik nongkrong di Mall atau pun di Kafe-kafe. Padahal melalui budaya barat inilah yang akhirnya para remaja menjadi pribadi yang hedonis, materialistis dan egois. Rasa memiliki, rasa kebersamaan, rasa persatuan dan rasa saling menegur akhirnya mulai pudar.

Bahkan menurut Kepala Sekolah SMKN I Simpangkates, Drs.Hendroyono, anakanak remaja saat ini sudah banyak yang tidak memiliki rasa sungkan atau hormat kepada orang tua. Ketika dinesehati, justru terdengar kata-kata ocehan dari belakang yang tidak enak di dengar. Sehingga ketika seorang guru banyak nasehatnya bukannya disukai akan tetapi justru ada sebagian yang membenci.

Selain budaya nganggung yang mulai pudar, ada juga yang mulai ditinggalkan bahkan nyaris tidak ada lagi yaitu budaya ngaji sesudah magrib baik ngaji di rumah maupun mengaji kepada guru ngaji. Menurut Drs.Sugianto, jika mengingat masa-masa remaja atau kecil dulu, dietiap kampung anak-anak remaja selalu disibukkan dengan mengaji setiap ba'da maghrib ${ }^{26}$. Mengaji tersebut, tentunya bukan hanya mengaji Al-Qur'an saja, akan tetapi mengaji masalah akidah, ibadah maupun akhlak. Makanya saat itu, kenakalan remaja maupun moralitas remaja masih terjaga.

Sementara saat ini, akibat dari arus informasi dan globalisasi serta akibat negatif sins dan tehnologi, anak-anak habis maghrib bukanlah sibuk mengaji, akan tetapi justru sibuk nonton TV atau nongkrong-nongkrong ngerumpi di tempat hiburan atau keramaian. Sehingga, yang menjadi tuntunan kehidupan bukanlah tuntunan agama akan tetapi tontonan yang dijadikan teladannya.

\section{Implementasi Muatan Lokal Berbasis Akhlak di Bangka Tengah}

Muatan Lokal ini diadakan untuk mengatasi alokasi waktu PAI yang hanya dua jam dalam seminggu. Menurut kepala sekolah SMP I Koba, Kabupaten Bangka Tengah

${ }^{26}$ Untuk itu, saat ini menurut Kepala Kementerian Pendidikan Nasional sedang dibuat Perda yang isinya diantaranya adalah tentang penerapan jam wajib belajar bagi pelajar mulai dari jam 18.00 -20.00. Diharapkan dengan penerapan waktu ini para pelajar mulai dari SD - SMA pada jam tersebut tidak boleh ada diluar rumah, akan tetapi diwajibkan belajar, baik belajar sekolah maupun belajar mengaji. Dengan kata lain, kewajiban orang tua mengawasi anak-anaknya agar tidak berkeliaran pada jam wajib belajar tersebut. Hal ini diterapkan sebagai lanjutan pembelajaran yang disekolah sampai sore, menjelang malamnya dilanjutkan di rumahnya masing-masing. (wawancara pada tanggal 1 April 2013, pada jam 18.30). 
Drs.Hartana, saat ini di sekolahnya sedang digalakkan pembinaan moral ${ }^{27}$. Awalnya, pembinaan moral ini akan diserahkan kepada guru Agama langsung, namun karena waktu mata pelajaran PAI yang sangat sempit maka pembinaan moral diambil di luar jam pelajaran PAI. Dengan demikian tanggung jawab pembinaan moral atau karakter siswa menjadi tanggung jawab bersama baik guru Agama maupun Guru-guru yang lainnya.

Menurut Komal, S.Ag, pembinaan moral ini memang tidak bisa jika hanya dibebankan kepada guru Agama saja, karena masalah moral atau akhlak bukan hanya tanggung jawab guru Agama akan tetapi tanggung jawab bersama, baik guru di sekolah, orang tua maupun lingkungan. Sebaik apapun pembinaan moral di sekolah jika guru yang lain, orang tua dan juga lingkungan tidak mendukung maka para siswa tetap akan terpengaruh oleh hal-hal negatif. Untuk itu, harus ada kerjasama atau pengawasan bersama terhadap prilaku siswa ${ }^{28}$.

Muatan lokal PAI yang dilaksanakan di SMPN 2 Koba belum terstruktur atau belum dibuat kurikulumnya. Hal ini disebabkan kurangnya SDM atau pengetahuan tentang cara menyusun kurikulum yang bernuansa islami atau akhlak ${ }^{29}$. Adapun model pembinaan kepribadian atau moral yang selama ini dilaksanakan di SMP 2 Koba yaitu :

\footnotetext{
${ }^{27}$ Wawancara dengan Drs.Hartana, pada tanggal 13 Februari 2013 di ruang Kepala Sekolah SMPN 2 Koba, Bangka Tengah.

${ }^{28}$ Wawancara dengan Komal, S.Ag, Guru Agama SMPN 2 Koba pada tanggal 13 Februari jam 14.00 di Ruang Guru SMPN 2 Koba, Kabupaten Bangka Tengah.

${ }^{29}$ Hal ini terbukti, ketika peneliti mewawancarai Drs.Hartana sebagai kepala sekolah SMPN 2 Koba, pada tanggal 13 Februari 2013 jam 14.30. Beliau mengatakan bahwa, sejak beliau memimpin sudah berusaha agar para siswa di sekolahnya memiliki kepribadian yang baik, sopan santun dalam bertutur kata, berprilaku selalu sesuai dengan tuntunan agama serta memiliki akhlakulkarimah. Namun kenyataannya ada siswa berprilaku yang sangat tidak bermoral, sehingga bukan saja membuat malu almamater sekolah akan tetapi juga memalukan dunia pendidikan di bangka tengah dan bangka belitung. Adapun perbuatan amoral siswa tersebut yaitu melakukan hubungan layaknya suami isteri yang diabadikan lewat video. Bahkan menurut pengakuannya hal ini dilakukan bukan hanya sekali tapi sudah berulang kali. Hal inilah yang akhirnya menjadi berita heboh se-babel baik berita lewat media cetak maupun elektronik (internet). Untuk itulah, Bupati Bangka Tengah akhirnya menggintruksikan kepada Dinas pendidikan agar lebih serius lagi mengadakan pembinaan moral di sekolah dengan cara membuat kebijakan seluruh sekolah tingkat SMP dan SMA sederajat harus masuk jam tujuh dan pulang jam 4 sore selama lima hari, sabtu minggunya libur. Namun demikian, sampai saat ini belum ada model kurikulum muatan lokal yang pasti untuk mengisi tentang pembinaan moral tersebut. Beliau mengatakan jika ada yang membuat atau menyusun kurikulum yang berbasis akhlak maka beliau sangatlah setuju. Hal ini sesuai dengan pernyataan sekretaris Diknas Koba Drs.Herwan, dan Kasi Keagamaan Erkandi, S.Ag serta Kasi Bimas Islam Syukri, S.Ag jika ada konsep atau model kurikulum muatan lokal berbasis akhlak maka mereka sangat setuju jika diterapkan di sekolah-sekolah yang ada di Bangka Tengah khusunya untuk tingkat SMP dan SMA. (Wawancara pada tanggal 14 Februari 2013 jam 9.30 di Diknas dan jam 10.00 di Kemenag).
} 
a. Pembinaan Budi Pekerti atau Kepribadian

Pembinaan budi pekerti atau kepribadian ini dilaksanakan oleh seluruh guru mata pelajaran. Setiap guru dianjurkan membina, membimbing serta membiasakan kepada para siswa agar melakukan perbuatan yang baik. Diantara kebiasaan itu terwujud dengan cara diawali dengan konsep tiga $\mathrm{S}$ yaitu senyum, sapa dan salam. Tiga $\mathrm{S}$ ini dilaksanakan sebelum para siswa masuk ke dalam kelasnya masing-masing. Adapun tujuan utama dari konsep ini adalah membiasakan para siswa agar memiliki rasa hormat, rasa sopan santun serta rasa tengagang rasa baik terhadap guru maupun kepada sesama kawannya sendiri. Melalui program ini diharapkan akan tumbuh rasa kekeluargaan dan rasa persaudaraan didalam lingkungan sekolah ${ }^{30}$.

Selain dibiasakan melaksanakan program tiga S, kebiasaan untuk menumbuhkan rasa keimanan pun selalu dilakukan dengan cara membaca do'a bersama dulu sebelum dan sesudah belajar. Hal ini memberikan pelajaran kepada siswa bahwa diluar kemampuan kita ada kemampuan lain yang luar biasa dahsyatnya. Bahkan tanpa adanya kendali kemampuan yangmaha dahsyat tersebut maka kita pun tidak akan memiliki daya dan upaya apalagi kemampuan dalam belajar kita. Pemilik kendali kemampuan tersebut adalah Tuhan kita yaitu Allah swt ${ }^{31}$. Untuk itu, setiap belajar kita harus berdo'a agar Allah selalu membukakan hati dan pikiran kita sehingga kita diberikan kemudahan dalam menerima setiap pembelajaran yang kita laksanakan. Inilah rahasia mengapa kita harus berdo'a sebelum dan sesudah belajar, agar kita selalu ingat bahwa sang maha pemberi peringatan dan

${ }^{30}$ Menurut Komal, S.Ag guru agama islam SMPN I Koba, kebiasaan ini sebenarnya dalam rangka mengamalkan firman Allah dalam Al-Qur'an yang menyatakan bahwa "sesungguhnya orang -orang mu'min itu bersaudara" bahkan dalam hadits nabi pun dikatakan bahwa orang mu'min yang satu dengan yang lainnya bagaikan satu bangunan antara yang satu dengan yang lainnya saling membutuhkan. Dengan kata lain, para siswa secara tidak langsung belajar mengamalkan perintah Allah dan Rasulnya. (wawancara pada tanggal 13 februari 2013 jam 13.30 di ruang kepala sekolah SMPN 2 Koba, kabupaten Bangka Tengah).

${ }^{31}$ Hal ini sesuai dengan firman Allah swt yang mengatakan bahwa sesungguhnya Allah berkuasa atas segala sesuatu. Dengan demikian, tiada satu makhlukpun di dunia ini yang memiliki daya dan upaya kecuali hanya dari Allah swt. Jika sudah tertanam sifat ini, berarti para siswa ini diharapkan nantinya menjadi siswa yang yakin akan adanya Allah swt dimanapun berada. Sebab, salah satu ciri orang yang sungguh-sungguh beriman dan bertaqwa adalah seseorang yang memiliki persaan takut kepada Allah dimapaun ia berada. 
pembelajaran yang sejati hanyalah Allah swt. Dengan demikian para siswa akan tumbuh keimanan yang kuat, serta semakin yakin kepada keberadaan Allah swt ${ }^{32}$.

b. Shalat Dhuha Bersama

Kegiatan shalat dhuha bersama ini dilaksanakan bergiliran antar kelas yang satu dengan yang alinnya. Bergiliran dalam pelaksanaannya dikarenakan kapasitas mushala sekolah yang tidak memungkinkan jika pelaksanaannya bersamaan. Untuk itu, dibutalah jadwal perkelas yang dipimpin langsung oleh guru Agama Islam. Shalat dhuha ini dilaksanakan untuk melatih siswa agar terbiasa melaksanakan shalat sunnah, serta melaksanakan sunnah rasulullah saw. Setelah shlat dhuha diadakan do'a bersama setelah itu salam-salaman.

c. Membaca Al-Qur'an

Setiap hari jum'at pagi sebelum belajar maka seluruh kelas dianjurkan untuk membaca Al-Qur'an bersama yang dipimpin oleh guru kelas masing-masing. Dalam pelaksanaannya terkadang menemukan kendala, jika guru yang berada dalam kelas tersebut adalam non muslim atau orang muslim akan tetapi kurang bagus dalam membaca AlQur'annya. Untuk mengatasi kendala tersebut, maka dicari salah satu siswa yang ada dikelas tersebut yang fasih bacaannya, kemudian ia diminta memimpin membaca Al-Qur'an bersama. Tujuan utama dari kebiasaan membaca Al-Qur'an ini agar siswa menjadi cinta terhadap Al-Qur'an, sehingga para siswa akan gemar membaca Al-Qur'an baik di sekolah maupun di rumahnya masing-masing ${ }^{33}$.

d. Mengadakan Ceramah Agama

Untuk menambah wawasan keislaman sekaligus membina mental atau moral anak, pihak sekolah pun sekali-kali mendatangkan penceramah atau da'i dari luar. Para muballigh yang dipanggil biasanya dari anggota atau pengurus MUI (majleis ulama Indonesia) kabupaten bangka Tengah atau penceramah lain yang sudah dikenal dikalangan masyarakat babel $^{34}$. Tujuan utamanya adalah memberikan siraman rohani maupun untuk menambah

${ }^{32}$ Hasil wawancara dengan kepala sekolah dan guru agama SMPN 2 Koba pada tanggal 13 Februari 2013

${ }^{33}$ Hasil wawancara dengan Drs. Sigid kepala sekolah SMPN I Koba pada tanggal 14 Februari 2013 jam 10.00 dan wawancara dengan Drs. Hartana kepala sekolah SMPN 2 Koba pada tanggal 13 Februari jam 14.00.

${ }^{34}$ Hal ini dibenarkan oleh Ketua MUI Bangka Tengah bapak KH.Hasyim Sya'roni, beliau mengatakan bahwa kadang-kadang saya diminta oleh beberapa sekolah untuk menyampaikan siraman rohani untuk anak-anak sekolah juga untuk para dewan guru. Kata beliau, sebenarnya tanpa diminta 
wawasan baik bagi anak-anak didik amaupun bagi para guru dan karyawan sekolah. Tentunya, sebelum penceramah tampil ada pesan-pesan khusus yang disampaikan agar materi yang disampaikan sesuai dengan kebutuhan atau problem yang sedang terjadi dilingkungan sekolah.

e. Membiasakan Shalat Berjama'ah

Di SMA I Namang dianjurkan kepada para siswa agar setiap waktu shalat melaksanakan shalatnya secara berjama'ah di mushalah. Tentunya melalui kebiasaan ini diharapkan siswa menjadi senang melaksanakan shalat wajib bahkan selalu dilakukan secara berjama'ah baik ketika di sekolah maupun di luar sekolah. Agar memotivasi siswa giat berjama'ah setiap kelas mengabsen siapa saja yang ikut berjama'ah dan yang tidak. Hasil absennya diserahkan kepada guru agama agar dijadikan acuan penilaian bagi para siswanya. Hal ini seperti yang dikatakan oleh Kepala sekolah SMKN I Simpang Kates, Drs.Hendroyono, sudah seharusnya penilaian pendidikan agama islam berorientasi pada nilai pengamalnnya bukan pada nilai hasil ujiannya. Sebab, tujuan pendidikan agama untuk dilaksanakan bukan untuk dihafalkan. Untuk itu, sepintar dan sebagus apapun nilai ujiannya jika prilaku atau pengamalannya buruk maka nilainya harus buruk, sementara walaupun sisiwa tersebut tidak baik nilai ujiannya tetapi baik prilaku dan pengamalan agamanya maka ia berhak mendapat nilai bagus. Dengan kata lain, orientasi PAI bukan nilai akan tetapi pengamalan ${ }^{35}$. Untuk itu, shalat berjama'ah serta kebiasaan senyum, sapa dan salam dapat dijadikan salah satu acuan atau barometer prilaku dan pengamalan sisiwa terhadap ajaran agamanya.

\section{E. Penutup}

Implementasi kurikulum muatan lokal (kearifan local) berbasis akhlak akan terlaksana dengan baik jika dalam pelaksanaannya disepakati oleh kalangan birokrasi yaitu Terutama Bupati dan Kepala Dinas Pendidikan. Selain oleh kalangan birokrasi juga harus

\footnotetext{
pun MUI memiliki kewajiban untuk memberikan pembinaan moral kepada para siswa. Apalagi untuk zaman sekarang, pergaulan, pengaruih lingkungan bagi anak-anak sangat mengkhawatirkan. Bahkan beliau sngat setuju jika bupati dan dinas pendidikan mewajibakan kepada tiap sekolah untuk mengadakan pembinaan moral atau akhlak diluar jam pelajaran sekolah. Saya dan yang lainnya siap datang ke sekolah-sekolah untuk memberikakan pembinaan tersebut apalagi sudah ada panduan atau kurikulumnya (hasil wawancara pada tanggal 15 Februari 2013 pada jam 17.00 di rumahnya).

${ }^{35} \mathrm{Ibid}$, pada jam 10.00
} 
disepakati oleh para praktisi yaitu para tokoh agama dan tokoh masyarakat, disepakati juga oleh para profesi yaitu para Guru PAI, Kepala sekolah dan guru-guru yang lainnya.

Dalam pelaksanaannya tentunya tiada program yang sempurna, untuk itu harus selalu diadakan pengembangan dan evaluasi program dengan cara menela'ah dan mengevaluasinya. Hal ini disebabkan tidak ada satupun konsep yang langsung sempurna, oleh sebab itu harus selalu ada perbaikan dan pengembangan disetiap waktu. 


\section{Daftar Pustaka}

Ahmad Muhaimin Azzet, Urgensi Pendidikan Karakter di Indonesia, Revitalisasi Pendidikan Karakter Terhadap Keberhasilan Belajar dan Kemajuan Bangsa, Arruz Media, Yogyakarta, 2011

A.Mustopa, Akhlak tasawuf, untuk fakultas Tarbiyah, Pustaka setia, bandung, 1997

Abudin Nata, Pendidikan Islam di Era Global, Pendidikan Multikultural, Pendidikan Multin Iman, Pendidikan Agama, Moral dan Etika, Jakarta, UIN Jakarta Pers, 2005

Abdurrahman An-nahlawy, Pendidikan Islam di Rumah, Sekolah dan Masyarakat, penerjemah: Shihabuddin, Gema Insani Press, Jakarta, 1996

Bangka Pos, Babel Jadi Pasar Narkoba:empat Polisi jadi Tersangka, Sabtu, 12 Januari 2013.

Bangka Pos, Sikap Kami, Video Porno Mengguncangkan Koba, 7 januari 2013.

Bangka Pos, Siswa Bakal Pulang Sekolah pukul 16.30 WIB, 11 Januari 2013

Dawam Raharjo, Ensiklopedi Al-Quran Tafsir Sosial berdasarkan konsep-konsep kunci, Paramadina, Jakarta, 1996

Didin Hafidhuddin, Modul Tafsir Mudhu'i Program Doktor Pendidikan Islam, di Program Pascasarjana Universitas Ibnu Khaldun Bogor, Jawa Barat, 2011

Departemen Agama RI. Al-Qur'an dan Terjemahnya, Jakarta, 1971

Hasan Langgulung, Beberapa pemikiran Pendidikan Islam, Bandung, PT 2A1- Ma'arif, 1980

Ismail M dkk, Paradigma Pendidikan Islam, Fakultas Tarbiyah IAIN Walisongo bekerja sama dengan Pustaka Pelajar, Yogyakarta, 2001

Iif Khairu Ahmadi dkk, Mengembangkan pendidikan berbasis keunggulan lokal dalam KTSP, Jakarta:PT.Pustaka Prestasi karya, 2012

Ibnu abdul hafidh Suwaid, Muhammad, cara nabi mendidik anak disertai dengan contohcontoh aplikatif dari kehidpan salafush shaleh dan ulama amilin, Al-I'tisham Cahaya Umat, Jakarta, 2010

Jamal Ma'mur Asmani, Buku Panduan Internalisasi Pendidikan Karakter di Sekolah, DIVA press, Yogyakarta, 2011 
Miller, dalam Munir Mulkhan, Cerdas di Kelas Sekolah Kepribadian, rangkuman Model Pengembangan Kepribadian dalam Pendidikan Berbasis Kelas, Kreasi Wacana, 2002

Wawancara: Bupati Bangka Tengah, Kepala Dinas Kementerian Pendidikan Nasional, Kepala sekolah SMPN 2 Koba, Kepala Sekolah SMAN 1 Namang, Guru Agama SMPN 1 Koba dan SMPN 2 Koba 